\title{
Bacterial Communities Associated with "Pompei Worms" from the East Pacific Rise Hydrothermal Vents: SEM, TEM Observations
}

\author{
F. Gaill, ${ }^{1}$ D. Desbruyères, ${ }^{2}$ and D. Prieur ${ }^{3}$ \\ ${ }^{1}$ CNRS, Centre de Biologie Cellulaire, 67, rue Maurice Günsbourg, 94200 Ivry-sur-Seine, France; \\ ${ }^{2}$ IFREMER, Centre de Brest, B.P. 337, 29273 Brest Cedex, France; and \\ ${ }^{3}$ Laboratoire de Zoologie, Université de Bretagne Occidentale, 29287 Brest Cedex, France
}

\begin{abstract}
A morphological study of bacteria associated with the "Pompei worm," Alvinella pompejana, collected from East Pacific rise hydrothermal vents, revealed four types of epidermal associations on the dorsal part of the animals: various single cells distributed on the animal tegument; clumplike associations located in the intertegumentary spaces; and filamentous bacteria associated with epidermal expansions, or inserted on the posterior parapodia. The bacterial morphologies were illustrated by SEM and TEM pictures and compared to bacteria previously described. The functional significance of these associations is discussed.
\end{abstract}

\section{Introduction}

The exceptional biomass of animal communities discovered in the close vicinity of the East Pacific Rise hydrothermal vents (2,500-2,700 meters depth) has been explained primarily by the occurrence of high local chemo-synthetic production by procaryotes [14]. However, the bacteria collected near the vents in the cold and well-oxygenated ambient seawater showed a weak chemosynthetic activity and appeared to be quickly dispersed [23]. Chemosynthetic production could occur particularly in seawater pockets, trapped and heated under the basaltic ground, in the cracks and clefts of the basaltic suface, and finally in close association with the hydrothermal fauna [23]. Several associations between bacteria and invertebrates have been described and studied. The most extreme case was represented by the pogonophora Riftia pachyptila Jones [1, $3,4,5,10]$. Different levels of bacterial associations were also noted for the two giant bivalves of the hydrothermal vents: Calyptogena magnifica Boss and Turner and the "Galapagos mussel" [6, 11, 19].

The "Pompei worms" (Alvinella pompejana) [7] build organic tubes on the edge of zinc sulfide chimneys, nicknamed "white smokers" [9]. In this environment, the hot, acid, reducing hydrothermal fluid, enriched with minerals (metallic sulfides, silicates, calcium) mix actively with the cold oxygenated sulfate-enriched seawater, Large amounts of dissolved gases (methane, carbon monoxide, hydrogen sulfide) are contained in these fluids [20]. This mixing 

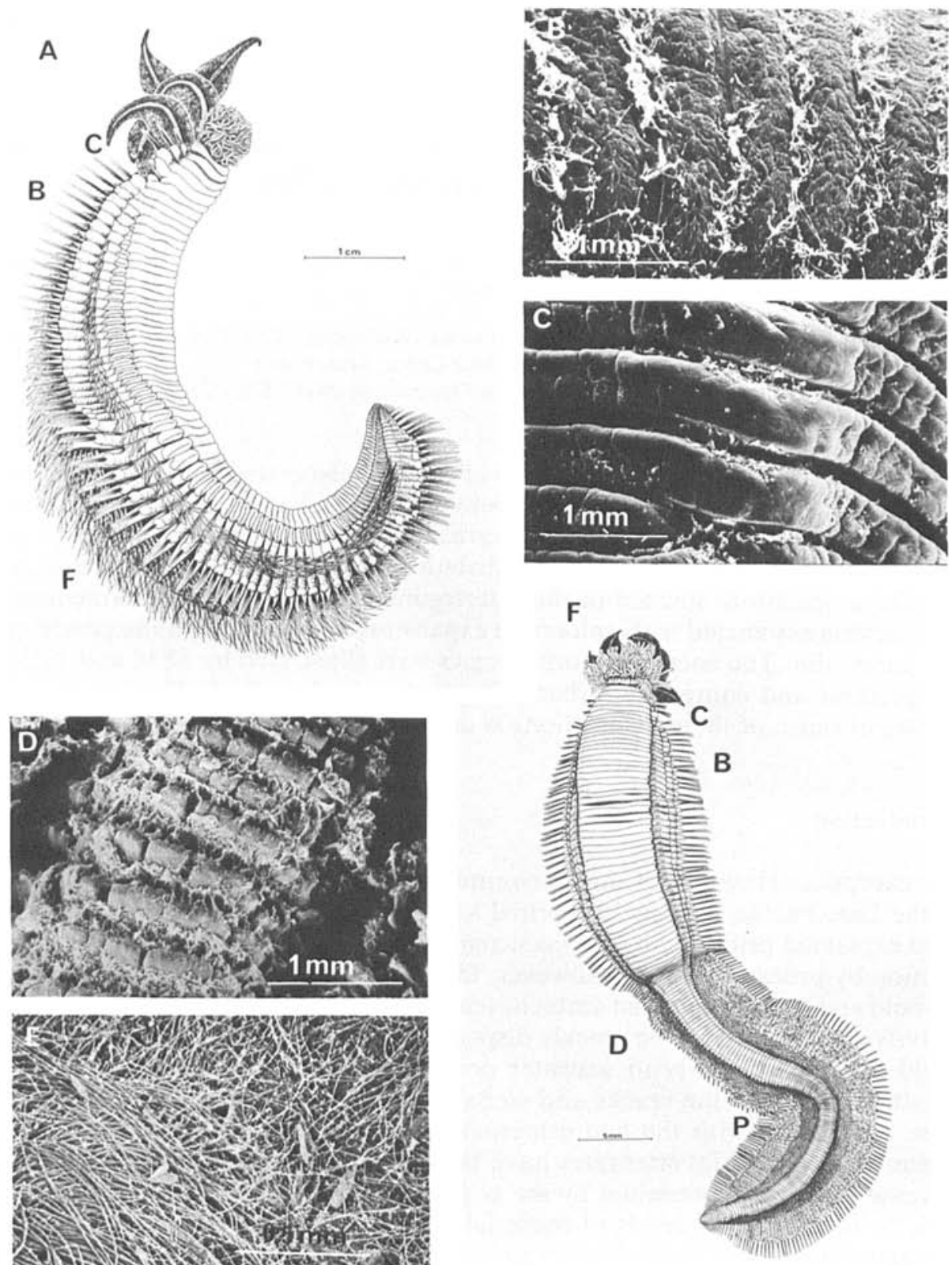

Fig. 1. Distribution of bacterial forms associated with Alvinella pompejana. (A) Drawing of Alvinella pompejana hirsuta. Epidermic expansions $(F)$ are numerous on the dorsal part of the worm. A low density of bacterial aggregates was observed in the most anterior part of the worm (C) (illustrated in Fig. 1C). The density of these aggregates increased in the intersegmentary spaces $(B)$ which are posterior to the part $C$ : this aspect is illustrated in Fig. 1B. (B) Segmentary part of the medioanterior dorsal area of the two forms of Alvinella pompejana. Bacterial aggregates were observed in the intersegment spaces. (C) Dorsal segmentary part of the fore areas of the two forms of Alvinella pompejana. Some aggregated bacteria were observed in the intersegmentary spaces. 
produced a sharp physiochemical gradient $(20-30 \mathrm{~cm})$ where numerous mineral precipitations (e.g., $\mathrm{Pb}, \mathrm{Zn}$, As) occurred [9]. In this extreme environment, which is particularly favorable for bacterial chemosynthesis, very productive animal communities prosper, predominated by Alvinellinae. Their biotope was located on the outer border of the thermal gradient $\left(20-40^{\circ} \mathrm{C}\right)$, but the hypothesis of incursions into warmer zones cannot be excluded. The observations of some transverse sections of diffusers revealed the presence of tubes up to the central part of the edifice, where the temperature exceeded $200^{\circ} \mathrm{C}$.

Numerous epibiotic bacteria live on these worms and inside their tubes $[8$, $9,12]$. However, no exhaustive description of these bacterial communities have been previously published. Scanning (SEM) and transmission (TEM) electron microscope observations of these bacteria are presumed here.

\section{Materials and Methods}

Alvinella pompejana specimens were collected at $20^{\circ} 50^{\prime} \mathrm{N}$ and $109^{\circ} \mathrm{W}$ with the research submersible "Alvin" (April-May 1979) and at $12^{\circ} 48^{\prime} \mathrm{N}$ and $103^{\circ} 56^{\prime} \mathrm{N}$ with the submersible "Cyana" (March 1982). The worms reached the deck about 2 hours after their in situ sampling at $2,600 \mathrm{~m}$ depth, at which time they were still alive. They were immediately dissected and fixed; some of them were kept alive during some hours under pressure. Ultrastructural studies were made on pieces of worms fixed with $0.4 \mathrm{M}$ sodium cacodylate-buffered glutaraldehyde ( $3 \%$ final concentration) at $\mathrm{pH} 7.2$ and then postfixed with osmium tetroxide (1\% final concentration) and embedded in Durcupan as described in Desbruyeres et al. [8]. Thin sections were stained with aqueous uranyl acetate and lead citrate, and examined with a Philips EM 201 TEM at the Centre de Biologie Cellulaire CNRS, Ivry, France. SEM observations were made on fixed samples dehydrated with ethanol, critical point dried, and sputter-coated with gold metal. The samples were examined with a Cambridge S100 SEM at the Ifremer, Centre de Brest, France.

\section{Results}

When the "Pompei worms" from the $21^{\circ} \mathrm{N}$ site on the east Pacific rise were described [7], two morphological forms living on the walls of the white smokers were considered the same species, thus hypothesizing two ontogenic stages [7]. More information about the relationship between the two forms is needed for a firm conclusion, but it has been proposed recently [9] that the names Alvinella pompejana forma hirsuta be given to the so-called "adult stage" and Alvinella pompejana forma caudata to the "juvenile stage." The morphological differences between the two forms primarily concern the number of setigerous seg.

(D) Posterior dorsal part of A. p. caudata epiderm. The segments are divided and the density of bacterial aggregates is extremely high. (E) Filamentous bacteria on the inner wall of the tube of Alvinella pompejana. Some unidentified crystals are included in the bacterial lawn. (F) Drawing of Alvinella pompejana caudata. The bacterial aggregates in the intersegmentary spaces $(B)$ and the anterior part of the worm $(C)$ were similar in both $A$. p. hirsuta and caudata, whereas their density increased in the posterior part $(D)$ of $A$. p. caudata (illustrated in Fig. 1D). This worm is devoid of epidermic expansions, and its posterior parapods $(P)$ are modified and covered with a high density of filamentous bacteria (see Fig. 5). 

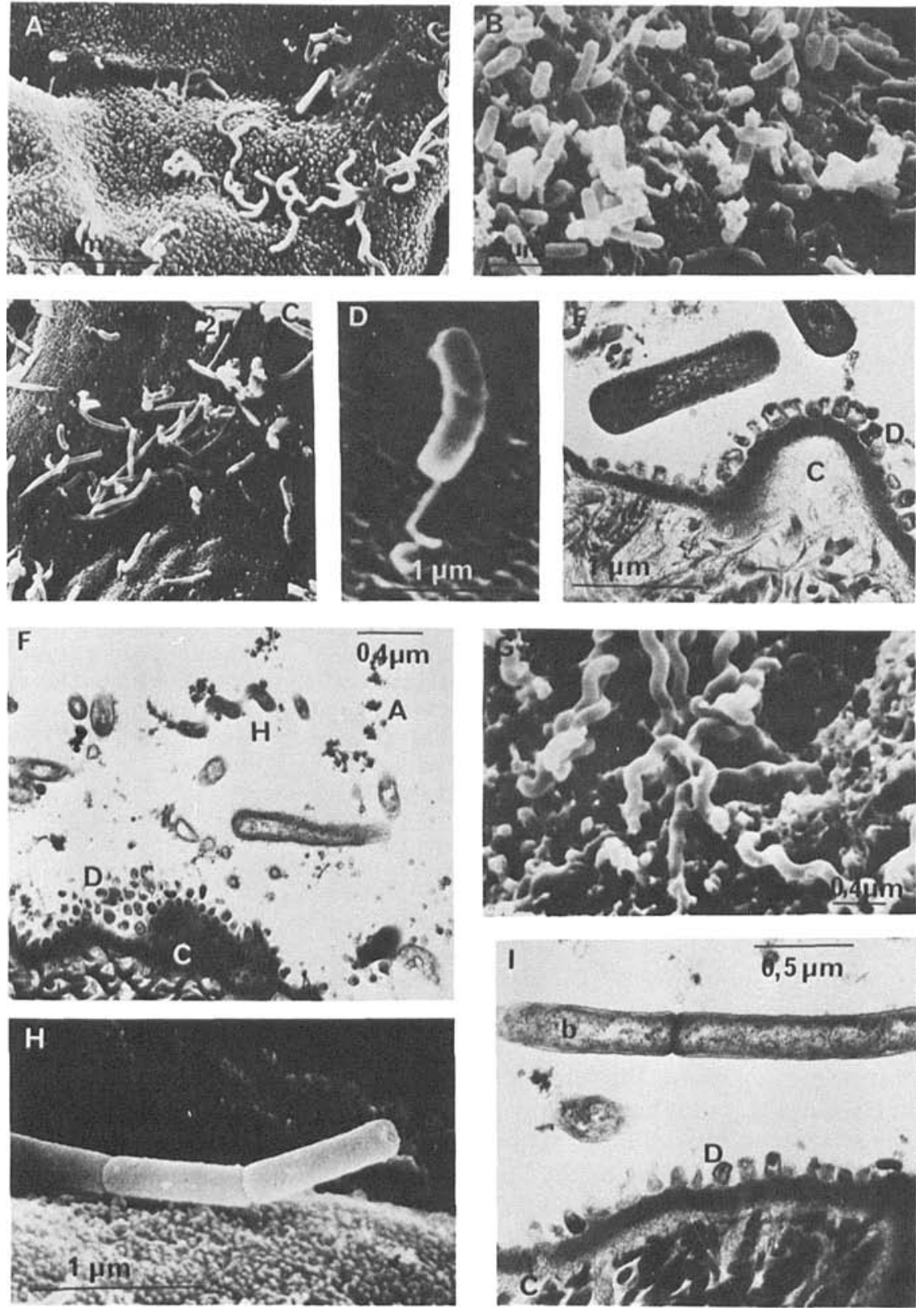

Fig. 2. Morphological types of bacteria observed on the teguments of the two forms of Alvinella pompejana. (A) Spiral-curved bacteria on the cuticle of $A$. pompejana. (B) Rod-shaped bacteria on the cuticle of $A$. pompejana. TEM observations of the same organisms are illustrated in $\mathbf{2 E}$ (below). (C) Rod-shaped bacteria on the cuticle of $A$. pompejana. (D) A high magnification of a rod-shaped bacteria which appeared 10 be appendaged. (E) TEM observations of rod-shaped bacteria. Thin filaments are noted between the rods and ellipsoid structures $(D)$ at the surface of the cuticle $(C)$. (F) Various types of bacteria on the surface of the cuticle $(C)$ under TEM observations, 
ments which are greater in most $A . p$. caudata specimens than in those of $A$. $p$. hirsuta. Another differentiating feature is a tremendous development of posterior parapodia in $A$. p. caudata.

Various bacterial morphologies were observed on the tegument of the two forms of $A$. pompejana sampled from the two sampling sites. The observed bacteria can be separated into four groups, according to their location on the epidermis of the worm (Fig. 1).

\section{Tegument Bacteria Without Any Particular Location}

These bacteria were observed on the two forms and can be classified into four morphological types, the first three types being the more abundant: (1) Rodshaped bacteria (Fig. 2B, C, D) $(1.2 \mu \mathrm{m} \times 0.3-0.6 \mu \mathrm{m})$ were often observed linked to the cuticle of the worm by thin filamentous structures (Fig. 2E, F); (2) Appendaged or prosthecate bacteria (Fig. 2C, D) of two different types: the first, about $2 \mu \mathrm{m}$ in length and $0.2 \mu \mathrm{m}$ in diameter in its distal part, the appendage being formed by a slow diminution of the cell diameter (Fig. 2C). The latter had a thicker cellular body and was prolonged by a thin, long, and distinct appendage (0.5 $\mu \mathrm{m}$ in length) (Fig. 2D); (3) Small spiral-curved bacteria $(2 \times 0.2 \mu \mathrm{m})$ (Fig. 2F, G) showing four spiral revolutions of $0.4 \mu \mathrm{m}$ step; (4) Unsheathed filamentous bacteria (Fig. $2 \mathrm{H}, \mathrm{I}$ ) with cells of $0.6 \mu \mathrm{m}$ length.

\section{Clumplike Bacteria}

In the intersegmentary spaces, the clumplike associations are inserted on axes which are perpendicular to the worm surface (Fig. 3B). The axis is surrounded with an organic matrix in which various bacterial types were inserted (Fig. 3A, C, D, E), particularly rod-shaped bacteria, coccoidal cells (Fig. 3B), and filamentous bacteria (Fig. 3A, B). TEM observations revealed the presence of a thin sheath filled with rod-shaped cells of variable sizes. The sheath was thicker $(0.3 \mu \mathrm{m})$ at the insertion level of the filament than at the extremity (Fig. 3F). At their ends, the large filaments were surrounded by smaller filamentous bacteria (Fig. 3G). Some bacterial cells observed under TEM appeared to be embedded in a thick amorphous matrix (Fig. 3E).

Bacteria Associated with the Dorsal Expansions of the A. p. hirsuta

The epidermis of the "hirsuta" form showed expansions, previously described as papilla, at the level of the dorsal intersegmentary parts (Fig. 4A). These

including spiral-curved cells $(H)$. Epicuticular projections $(D)$ seemed to be linked to the bacteria by their filaments. A mineral-like deposit $(A)$ was also present. (G) Spiral-curved bacteria. $(\mathbf{H})$ Unsheathed filamentous bacteria. (I) TEM observations of unsheathed filamentous bacteria $(b)$. $C$ : cuticle; $D$; epicuticular projections. 

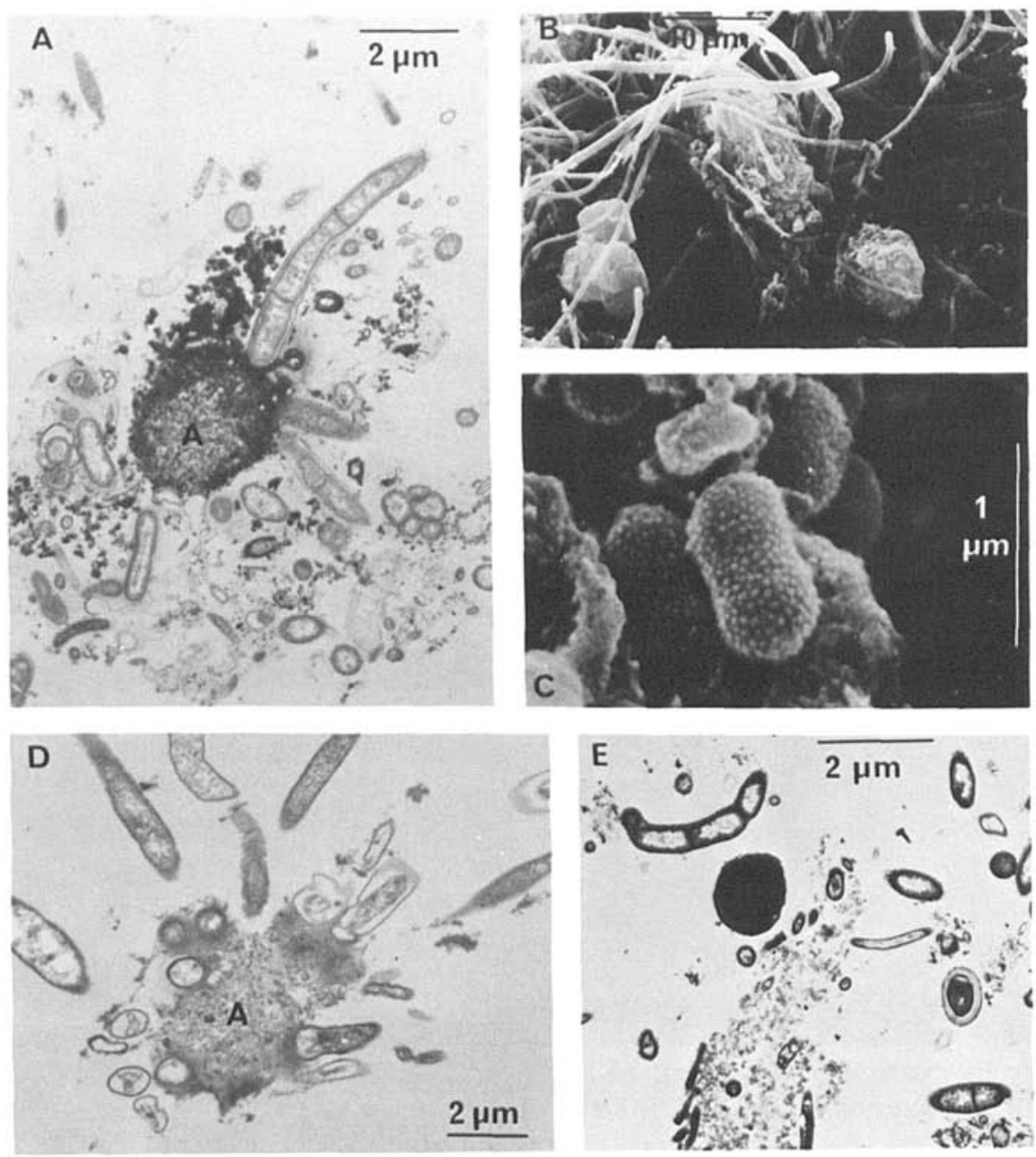

$\theta$
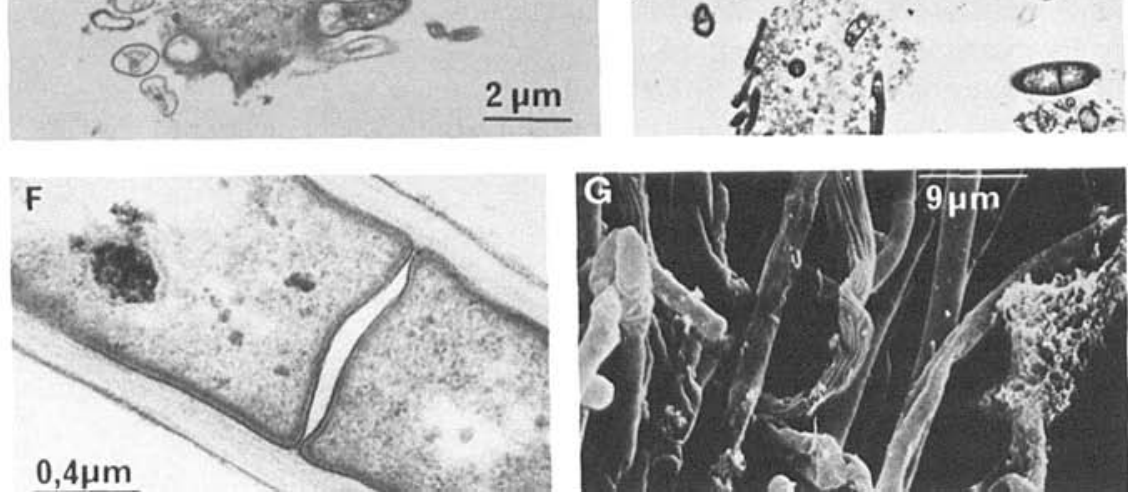

Fig. 3. Bacterial aggregates. (A) TEM general views of bacterial aggregates. Various bacterial cells are inserted around an axis $(A)$. The axis is composed of cuticular fibrils which are embedded in a matrix, which is surrounded by minerals in the distal part of the axis. (B) SEM general view of bacterial aggregates. Filamentous and coccoidal bacteria are observed around the axis which is perpendicular to the worm surface. (C) High magnification of nonfilamentous bacteria from $B$. (D) TEM observations of bacterial aggregates with degenerating cells. Cuticular fibrils are embedded in an amorphous matrix. (E) TEM patterns of aggregated bacteria. (F) High magnification of a 
expansions reached $10 \mu \mathrm{m}$ in length and could be observed with the naked eye. Filamentous bacteria (100-200 $\mu \mathrm{m}$ in length) were joined to the generative part of these cylindroconical structures (Fig. 4B). Different aspects of the filamentous bacteria are illustrated in Fig. 4E, F, G, H. Unidentified disks were usually among the bacteria (Fig. 4C, D).

\section{Bacteria Associated with the Parapodia of A. p. caudata}

The parapodia on the posterior portion of the "caudata" form showed several expansions on which filamentous bacteria were attached (Fig. 5A, B, E). These filaments were very large $(600 \times 2.5 \mu \mathrm{m})$ (Fig. 5C) and were easily observed with the naked eye. The cuticle of the worm was modified where the bacterial filaments were attached and often disappeared (Fig. 5E). The filaments were not sheathed and were composed of large (up to $6 \mu \mathrm{m}$ ) bacterial cells, with a range of diameter from $0.3-2 \mu \mathrm{m}$ (Fig. 5B). Some unidentified crystals were observed among the filaments (Fig. 5D). Some inclusions were in the bacterial cells (Fig. 5F), which generally had a thick cell wall with no sheath (Fig. 5G).

\section{Discussion}

Morphological patterns of several microorganisms associated with the deepsea hydrothermal communities were previously described $[5,8,15]$. Unlike the Pogonophora [5] or bivalve molluscs from these communities [6], the two forms of $A$. pompejana do not seem to have intracellular bacteria. On the other hand, the teguments of the worm are covered with many microorganisms of various types. The most common single cells are gram-negative rods, but these bacteria are widespread in the marine environment and their identification is impossible using only the morphological features reported here. Because of the lack of typical periplasmic fibrils, the spiral curved bacteria are not spirochetes and may be related to the genus Spirillum [17], with a chemoorganotrophic metabolism. The filamentous bacteria associated with $A$. pompejana are the most abundant and, in some cases, can be observed with the naked eye. Some of them are unsheathed, but they are usually formed by rods in chains within a sheath. Thus, they are different from the Leucothrix-like and Thiotrix-like bacteria that have been observed on the shell of the Galapagos mussel [15]. Because of their large size, some filaments could be related to the genus Beggiatoa [15]. However, this genus has been described as free living, and the filaments observed here were attached to the tegument of the worm. Moreover, no sulfur inclusion was observed within the worm-associated filaments. Never-

bacterial filament. Bacterial cells are surrounded by a thin sheath. (G) Distal ends of filamentous bacteria protruding from the aggregates. Some appeared collapsed. Smaller filamentous bacteria surround some large filaments. These patterns are common on the distal parts of epidermic expansions. 

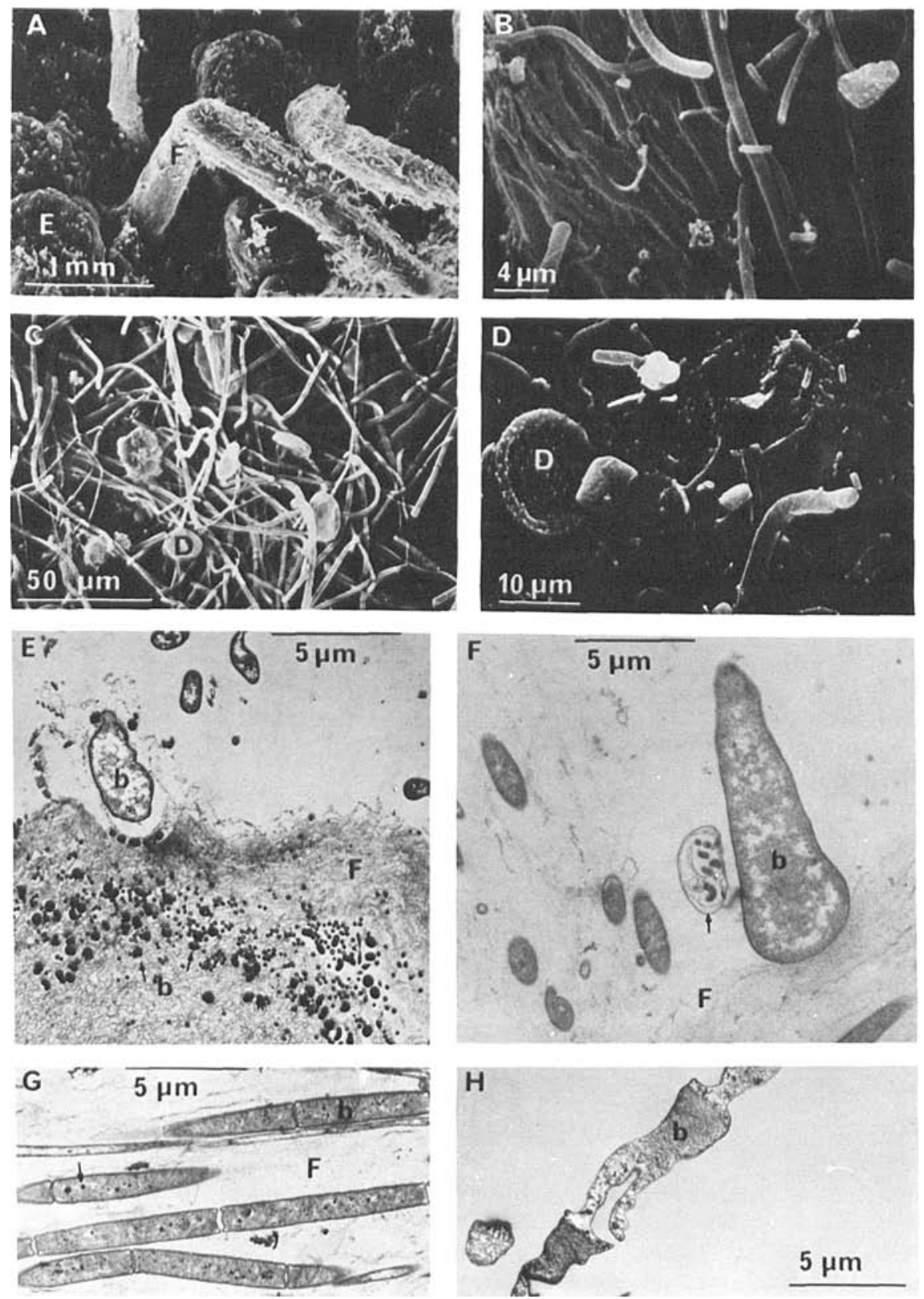

Fig. 4. Bacteria associated with the epidermic expansions of $A$. p. hirsuta. (A) SEM observations of the intersegmentary epidermic expansions $(F)$ and a segmental part of the dorsal integument $(E)$. (B) These expansions are made of a fibrillar matrix covered with bacteria. $(C)$ Small disks $(D)$, included in the bacterial lawn, are located near the base of the expansions. (D) Higher magnification of disks $(D)$ located near the base of the expansions. (E) TEM observations of bacteria $(b)$ around the organic layer $(F)$ of epidermic expansions. The larger types of bacteria are inserted in the organic 

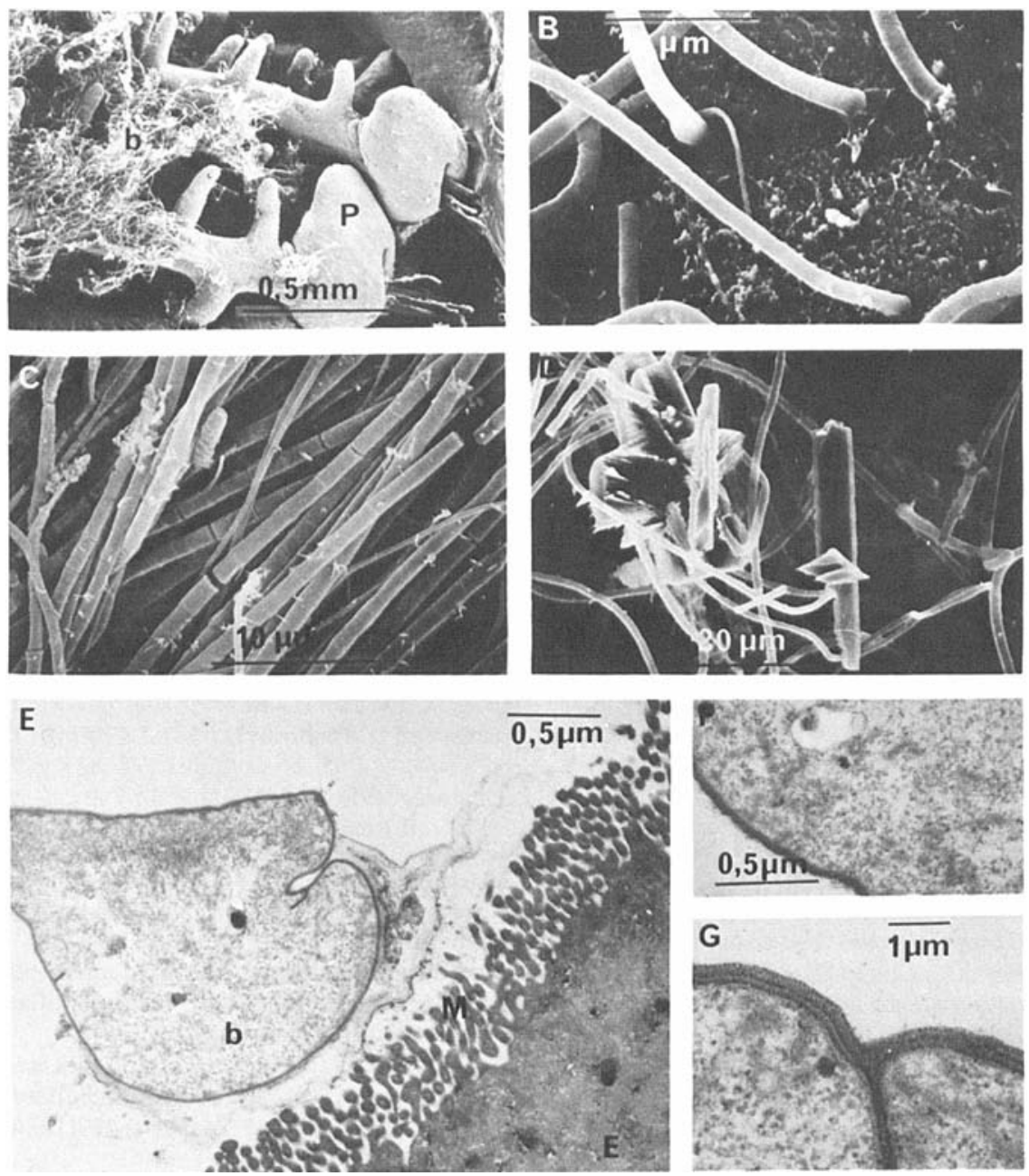

Fig. 5. Bacteria associated with the parapods of the A. p. caudata. (A) SEM general view of the parapods $(P)$ after removal of epibiotic bacteria $(b)$. (B) SEM observations of filamentous bacteria inserted on the cuticle. The bases of the filaments are enlarged. (C) Bacterial filaments from the inner walls of the worm tube. (D) Bacterial filaments associated with the parapods, showing some unidentified crystals. (E) TEM observations of a bacterial filament $(b)$ inserted near the microvilli $(M)$ of the cell epidermis $(E)$. No cuticle was observed. (F) TEM observations of a bacterial cell with an inclusion. (G) Detail of the cell wall of the filamentous bacteria.

layer. (F) Median part of the epidermic expansion $(F)$ with large bacteria $(b)$. A corpuscule (possibly Bdellovibrio-like) was observed (arrow). (G) TEM observations of filamentous bacteria in the median part of epidermic expansions $(F)$. Dark granules (arrow) occur in the bacteria $(b)$. (H) Distal part of filaments with collapsed bacteria $(b)$. 
theless, sulfur could play a role in the metabolism of these bacteria, as sulfur crystals have been noted [18] among the parapodial filaments. Using only morphological features, it is not possible to identify the filamentous forms described here, and more investigations on physiological characteristics of these organisms are needed.

With invertebrates living far from the vent ecosystem, some epibiotic bacterial associations have been described $[2,16,21,22]$. The polychaetous annelids commonly have lacked associated bacteria [21].

The functional significance of the epibiosis of $A$. pompejana is not understood. Epibiotic bacteria might use inorganic compounds from the hydrothermal vents and the worm metabolism, as well as organic compounds secreted by the worm. In return, the worm presumably may use the dissolved organic compounds produced by the bacteria. Beyond the possible but as yet undemonstrated trophic relationships between $A$. pompejana and its associated bacteria, some other relationships can be considered, particularly detoxification. The environment of the worm is enriched with hydrogen sulfide and metallic compounds. Although high concentrations of arsenic have been noted in the integuments of $A$. pompejana [13], it is possible that some bacteria concentrate the metals and thus help to detoxify the environment near the worm.

\section{References}

1. Arp AJ, Childress JJ (1981) Blood function in the hydrothermal vent vestimentiferan worm. Science 213:342-344

2. Bodamer JE, Sawyer TK (1981) Aufwuchs protozoa and bacteria on the gills of the rock crab, Cancer irroratus Say: a survey by light and electron microscopy. J Protozool 28:35-46

3. Bosch C, Grasse PP (1984a) Cycle partiel des bactéries chimiautotrophes symbiotiques et leurs rapports avec les bactériocytes chez Rifiia pachyptila Jones (Pogonophore vestsimentifère) I. Le trophosome et les bactériocytes. CR Acad Sci (Paris) 299:371-376

4. Bosch C, Grasse PP (1984b) Cycle partiel des bactéries chimiautotrophes symbiotiques et leurs rapports avec les bactériocytes chez Riftia pachyptila Jones (Pogonophore vestimentifère) II. L'évolution des bactéries symbiotiques et des bactériocytes. CR Acad Sci (Paris) 299(10):413419

5. Cavanaugh CM, Gardiner SL, Jones ML, Jannasch HW, Waterbury JB (1981) Prokaryotic cells in the hydrothermal vent tube worm Riftia pachyptila Jones: possible chemoautotrophic symbionts. Science 21 3:340-341

6. Cavanaugh CM (1983) Symbiotic chemoautotrophic bacteria in marine invertebrates from sulphide-rich habitats. Nature 302:58-61

7. Desbruyeres D, Laubier L (1980) Alvinella pompejana gen., Ampharetidae aberrant des sources hydrothermales de la ride Est-Pacifique. Oceanologica Acta 3(3):267-274

8. Desbruyeres D, Gaill F, Laubier L, Prieur D, Rau GH (1983) Unusual nutrition of the "Pompei worm" Alvinella pompejana (polychaetous annelid) from a hydrothermal vent environment: SEM, TEM ${ }^{13} \mathrm{C}$ and ${ }^{15} \mathrm{C}$ evidence. Mar Biol 75:201-205

9. Desbruyeres D, Gaill F, Laubier L, Fouquet Y (1986) Polychaetous annelids from hydrothermal vent ecosystems: an ecological overview. In: Jones MI (ed) The hydrothermal vents of the eastern Pacific. An overview. Bull Biol Soc Washington 6:103-116

10. Felbeck H (1981) Chemoautotrophic potential of the hydrothermal vent tube worm Riftia pachyptila Jones (Vestimentifera). Science 213:336-338

11. Fiala-Medioni A (1984) Mise en évidence par microscopie électronique à transmission de l'abondance de bactéries symbiotiques dans la branchie de Mollusques bivalves des sources hydrothermales. CR Acad Sci (Paris) t 298, ser. III, 17:487-492 
12. Gaill F, Desbruyeres D, Prieur D, Gourret JP (1984) Mise en évidence par la microscopie électronique des communautés bactériennes épibiontes des "vers de Pompéi" (Alvinella pompejana). CR Acad Sci (Paris) t 298, ser. III, 19:553-558

13. Gaill F, Halpern S, Quintana C, Desbruyeres, D (1984b) Présence intracellulaire d'arsenic et de zinc associés au soufre chez une Polychète des sources hydrothermales. CR Acad Sci (Paris) t 298, ser. III, 12:331-335.

14. Jannasch HW, Wirsen CD (1979) Chemosynthetic primary production at East-Pacific sea floor spreading centers. Bioscience 29(10):592-598

15. Jannasch HW, Wirsen CO (1979) Morphological survey of microbial mats near deep-sea hydrothermal vents. Appl Environ Microbiol 41(2):528-538

16. Johnson I, Flower N, Loutit MW (1981) Contribution of periphytic bacteria to the concentration of chromium in the crab Helice crassa. Microb Ecol 7:245-252

17. Krieg NR, Smibert RM (1974) Family I. Spirillaceae Migula 1984. 237. In: Buchanan RE, Gibbons NE (eds) Bergey's manual of determinative bacteriology, 8th ed. The Williams and Wilkins Company, Baltimore, pp 196-212

18. Laubier L, Desbruyeres D, Chassard-Bouchaud C (1983) Microanalytical evidence of sulfur accumulation in a polychaete from deep-sea hydrothermal vents. Marine Biology Letters (4): 113-116

19. Le Pennec M, Prieur D (1984) Observations sur la nutrition d'un mytilidae d'un site hydrothermal actif de la dorsale du Pacifique oriental. CR Acad Sci (Paris) t 298, ser. III, 17: 493-498

20. Lilley MD, Baross JA, Gordon LI (1983) Reduced gases and bacteria in hydrothermal fluids: the Galapagos spreading center and $21^{\circ} \mathrm{N}$ East-Pacific rise. In: Rona PA, Bostrom K, Laubier L, Smith KL (eds) Hydrothermal processes at seafloor spreading centers. Nato Plenum. Press Conf Ser IV, 1983

21. Sieburth J McN (1975) Microbial seascapes. University Park Press, Baltimore

22. Sochard MR, Wilson DF, Austin B, Colwell RR (1979) Bacteria associated with the surface and gut of marine copepods. Appl Environ Microbiol 37(4):750-759

23. Tuttle JH, Wirsen CO, Jannasch HW (1983) Microbial activities in the emitted hydrothermal waters of the Galapagos rift vents. Mar Biol 73:293-299 